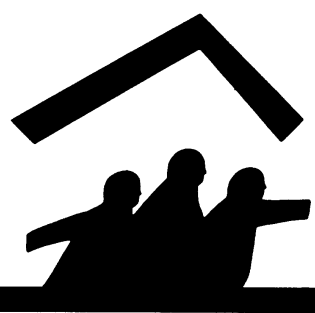

SPECIAL SECTION

\title{
Refugees in Central America
}

\section{Guatemalan Refugees in Mexico}

by Hubert Campfens

\author{
Guatemalan Refugees In Mexico \\ by Jeremy Adelman
}

A squadron of five helicopters swooped down over the sleepy village, awakening the population with a barrage of gun fire and killing several villagers who were out in the open and unable to find shelter. A few days later, a troop of some hundred soldiers surrounded the area making escape impossible. They closed in and demanded a village assembly in the main square. The officer told the villagers that they had 15 days to "repent their sins" and admit their support of the guerrilla movement. The officer expected the villagers to come forward with names of people who were guerrilla members, or families who harboured and fed them. If they didn't, they would witness a far greater retribution than they had experienced a few days before. Stories of military atrocities carried out in other villages, and this particular experience, were enough to have the Perez family and some 50 others pack up their meager belongings and start their long trek through the Guatemala forests into Mexico.

\section{Numbers}

The total number of refugees in Mexico from Guatemala is now estimated at 200,000. (The most recent large entry occurred in June 1983, in the Ococingo area of Chiapas where some 1,000 refugees crossed the border en masse.) Some 90,000 of these, principally children, women and older people, reside across a narrow strip along the Mexico-Guatemala border with the highest concentration found in the San Cristobal region where there are 77 settlements and 18 camps with 45,000 refugees.

\section{Background}

Guatemalan refugees in Mexico are primarily in-
In Guatemala, the long history of ruthless military dictatorship reached its apex under the recently deposed regime of Efrain Rios Montt. Since the overthrow of Jacobo Arbenz Guzman's government in 1954, the military has exercised an uninterrupted control over the country. In the last 30 years, an estimated 50,000 to 80,000 people have died at the hands of the military the vast majority of them peasants and rural workers. In recent years the violence has intensified under the rules of Generals Lucas Garcia and Rios Montt. In the face of rising opposition worker mobilization (particularly resulting from the reconstruction efforts following the earthquake of 1976), the government established a conscious policy of subverting possible opposition.

The first phase of the policy was targeted at community leaders (in particular, clerical workers). As phase one failed to counteract the mounting activity of the guerrilla movement, a second phase was institutionalized under Lucas Garcia and intensified under Rios Montt which involved bombing and large-scale harrassment. Its intent was to destroy the "base" of guerrilla activity. The increased repression involved destroying food supplies by burning peasant fields and killing livestock, as well as systematic elimination of "suspected" guerrillas. Moreover, the repression assumed a racist dimension as most of the perceived opposition was seen to come from the Indian populations $(60 \%$ of the country).

Following the coup d'etat in March of 1982 which brought Rios Montt to power, some speculated that the spiral of political violence would cease. Instead, matters worsened. On July 30, 1982, Rios Montt 
CAMPFENS cont'd from page 7

digenous people belonging to various tribes of the Maya people such as the Quiches, the Ixiles, and the Ketchis. Proud of their culture, ethnic and family traditions, almost all are poor farmers or small tradesmen. Most come from the high plains where they took shelter after the Spanish Conquest and during successive regimes. None of the ruling elites were prepared to give the Indian population even a limited opportunity to participate in the political, social and economic life of the country. Given their numbers and cultural homogeneity, the indigenous Maya people are apparently considered a major threat to the ruling oligarchy rooted in the small elite of non-Mayan descent.

As a consequence of the state's policy and military strategies, Indians have had to abandon their centuries-old habitat in the high plains; they have seen their communal mode of living broken and they have lost their link to the earth of their forefathers. To safeguard the only thing of value left, i.e., life, often suffering from torture and mutilation, they wandered through the forests and mountains, hiding in inhospitable places often up to 12 months with a bare minimum of clothes, food, or medicine, eating tree roots and leaves. Thousands died during this long trek due to malnutrition and illness. Many more who made it across the border into Mexico died as a result of their deplorable health conditions.

Personal testimonies, assembled and documented by the Mexican Commission for Aid to Refugees (COMAR), provide evidence of the planned violence aimed at systematically exterminating the indigenous Maya people and their culture in Guatemala. This interpretation of the facts is quite distinct from the Guatemalan official line which presents the basic struggle as a confrontation between capitalism and communism.

\section{Immediate Causes}

The military counter-insurgency operation of the Guatemalan Army consists of four basic strategies:

- a "scorched earth" policy aimed at isolating the guerrillas from the Indian population which is accused of providing shelter, feeding the guerrillas, and providing recruits;
- the creation of "strategic hamlets" where those dislocated by the burning villages and massacres can be limited in their activities and brought under strict control of the army;

- the establishment of a "civil defense" into which young and older men are recruited to "spy" on their own people for any possible links with the guerrillas;

- a "civic action" programme, as part of a so-called "rural pacification" policy, that forces the Indian population to rebuild that which has been burned by the military and to engage in public works for the army.

In Guatemala's interior, the army continues its excesses while the outside world is largely kept ignorant of the real facts. How many would venture into the interior for first-hand observation and interviews after the slayings of three Dutch reporters in 1982? Such a situation has given the military the upper hand in manipulating the media and world public opinion. The refugees themselves fear reprisal if they speak about the atrocities.

\section{Incursions of the Guatemalan Army Into Mexican Territory}

Not only has the Guatemalan army been active within its own country, it has attempted to maintain strong physical and psychological control over the lives of Guatemalan refugees outside its borders through a campaign of intimidation, terror, and repression. From October 1982 to the present, military incursions have occurred, often unopposed and, sometimes several kilometres deep into Mexican territory aimed at refugee camps and settlements; the Guatemalan soldiers robbed, destroyed and killed.

\section{The Diplomatic Offensive}

A diplomatic offensive initiated in February of this year (in anticipation of the Papal visit), and continued into the month of May, was an attempt by the Guatemalan government of Rios Montt to seek repatriation of all the Guatemalan refugees residing in Mexico through peaceful, more persuasive means.

The first link in this offensive involved a visit to Mexico by the Guatemalan Red Cross. This organization agreed to serve as guarantor for the general amnesty offered to the refugees by the government. The Guatemalan radio served as a second link, broadcasting the "good" news across the border, while the Guatemalan Consul in the Mexican city of Comitan in the State of Chiapas used the local radio to exhort refugees to return to their place of birth. Furthermore, it was learned from information passed on to the Mexican press (Feb.22) by several Mexican farmers residing in the area that members of the Guatemalan "civil defense" had entered many refugee camps to harrass refugees and plead with them in the name of the Guatemalan government to return to their country. Finally, in May, various missionaries of the American Christian Fundamentalist sect to which the Guatemalan president Rios Montt also belonged (Gospel Outreach of Eureka California), arrived in the Tziscao zone of Mexico bordering Guatemala with the objective of convincing refugees of the peace that would await them upon return with the guarantees offered by a "Christian" president.

As COMAR put it (July 1983): "In general, the Guatemalan refugees do not (allow) themselves (to be) misled by this type of campaign. People who continue to leave Guatemala seeking refuge from the massacres perpetrated by Rios Montt's army are the best witnesses to the deceitfulness and untruth of these invitations extended by this regime. There (can be) no peace in Guatemala while horrors,... denounced by different international tribunals, (continue). Evidence gathered by eyewitnesses indicates that those refugee families who, deceived by this propaganda, returned to their place of origin, and were brutally murdered upon arrival." (This release, no doubt, was issued by the external wing of COMAR.)

\section{The Mexican Response}

Mexico, which even up until 1981 expelled thousands of refugees from Guatemala and did not until 1982 sign the UN Convention dealing with the protection and basic rights of refugees, has become one of the world's major recipient countries for displaced persons, principally from Guatemala and El Salvador. The total number from these countries presently residing within Mexico is estimated to be anywhere from 200,000 to 250,000 . Considering that a staggering one million Guatemalans (out of a population of 7 million) are dislocated by the Civil War and in hiding somewhere in the interior of that country, many more tens of 


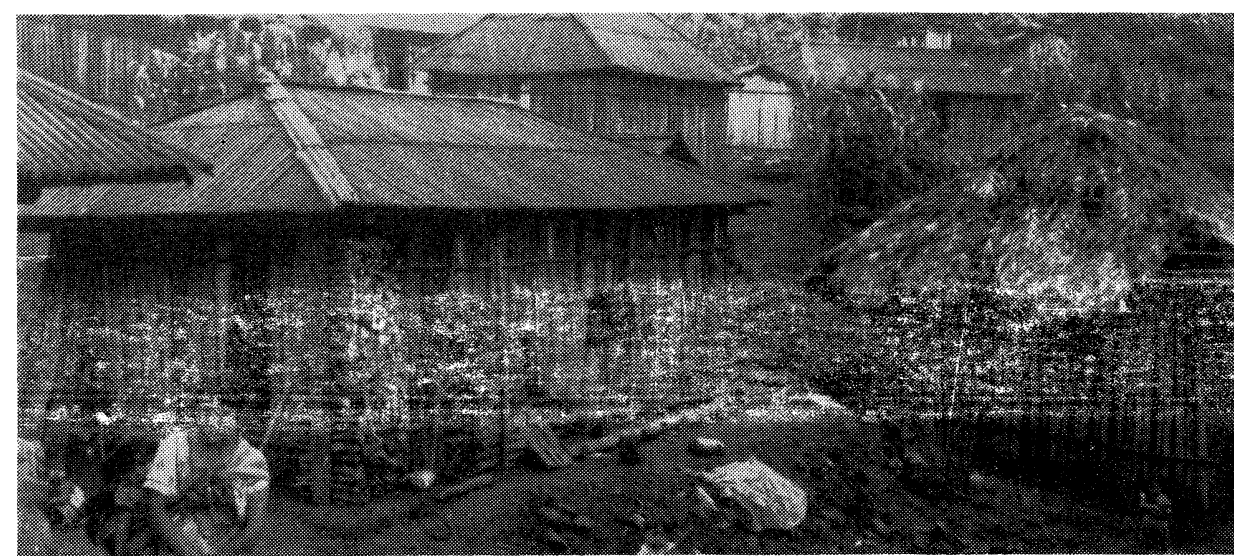

Photo: J. Adelman 1983

La Cascada Settlement, Chiapas

thousands can be expected to eventually cross the border, either seeking refugee status or as illegal immigrants.

Some Mexican authorities consider the continuing migration flow across the border to be a destabilizing factor both politically and economically. A series of measures has been introduced recently to put the brakes on the swelling numbers of refugees.

Mexico's deep economic troubles and the huge number of unemployed and under-employed among the 70 million people of Mexico provide reason for Mexican authorities to be cautious in allowing more refugees to enter the country even though most Guatemalans and other Central Americans do not enter Mexico to seek work or to improve their standard of living, but rather to flee repression with an explicit desire to return as soon as the hostilities come to an end.

Refugees within Mexico are required to carry special passes which call for renewal every three months. These passes provide a lease on life for refugees, and at the same time Mexican authorities can bide their time hoping for a political solution within Guatemala. Refugees can stay in Mexico as long as they refrain from using that country as a stopover for eventual entry into the United States. Mexico cannot ignore legitimate U.S. apprehensions about the estimated half-million illegal Latin American migrants (including Mexicans) entering the United States each year, nor resulting U.S. pressure to contain the influx of Central Americans within Mexico. However, American official motives are less plausible with reference particularly to Salvadorean and Guatemalan refugees in the United States. After all, the U.S. sends military aid to the two coun- tries and implicitly supports the counterinsurgency strategies carried out in the very region from which the largest number of refugees originate.

Mexico's official public response may be reluctant, yet, the Mexican people have been extremely generous to the refugees. (Spokesmen of voluntary agencies did not want to be too harsh and critical of Mexican official policies. As they pointed out, the government is in a political dilemma vis-a-vis the United States, and at least tolerates the voluntary sector doing its bit.)

Fears were expressed by some refugee workers about possible friction between local Mexican farmers and refugees because of the scarce resources available, but no such tension was apparent. On the contrary, Mexican Indians seemed to readily share their meager belongings with the Guatemalan Indian refugees and welcomed the opportunity of extending a helping hand to their own people from across the border. As far as the larger Mexican landowners are concerned, they look upon refugees as a new source of cheap labour to be exploited in the coffee and cotton plantations, working under inhuman conditions. The refugees working in such settings hardly complain for fear of being sent back to Guatemala. Refugees in the older settlements and camps, with the assistance of Mexican volunteers, have organized and mobilized their own people to the point where they are able to meet many of their own basic needs (i.e., clothing, food preparation, primary health care, shelter) but they cannot be fully selfreliant as a community unless they have land to produce their own food and feed their families.

One of the most supportive and influential individuals related to refugee work in Mexico is the Bishop of San Cristobal, Monsignor Samuel Ruiz, who is the church leader for the diocese that contains the largest concentration of refugee settlements and camps in Mexico. A "progressive" bishop among a generally "conservative" college of over 100 Mexican bishops, he has spoken out strongly against attempts at returning refugees to their country. A Catholic Solidarity Committee within his diocese leads and coordinates refugee help.

The Solidarity Committee is currently working on long-term plans that involve renting land from neighbouring large landowners to be farmed by the refugees for their own food production. This would help significantly to reduce the dependency level of refugees on the Mexicans, to diffuse possible tension in the region where local farmers are tested in their patience and increase selfesteem among the refugees themselves. This land rental plan would also help distribute the burden of supporting the refugees to the nation at large and to other countries like Canada through financial contributions.

\section{Mexican Views on Canada's Role}

Mexican voluntary officials active with refugees felt that Canadians could assist in several ways:

1 . by actively supporting and promoting the peace initiative of the Contadora group of nations (Mexico, Colombia and Venezuela);

2. by taking a stronger stand against the increased U.S. military build-up in Central America, and the general militarization of the region;

3. by speaking out against the flagrant abuse of human rights by the Guatemalan army;

4 . by supporting morally and financially the work of the Mexican and Canadian voluntary organizations active in alleviating the problems experienced by refugees in Mexico, such as the work carried out by Canada's major Christian churches, Oxfam and others;

5. by taking in a sizeable number of Guatemalan in-homeland refugees or those currently in Mexico who are uprooted victims of civil war lacking adequate protection for their safety and fearing persecution by the Guatemalan state.

Hubert Campfens is a professor of Social Work at Wilfrid Laurier University, Waterloo, Ontario. 